\title{
IMPLIKASI KEBIJ AKAN “PENDAERAHAN” PENGELOLAAN PBB SETELAH BERLAKUNYA UU NO. 28 TAHUN 2009 TENTANG PAJ AK DAERAH DAN RETRIBUSI DAERAH
}

\author{
Kadar Pamuji \\ Fakultas Hukum Universitas J enderal Soedirman Purwokerto \\ E-mail : kadarpamuji@yahoo.co.id
}

\begin{abstract}
Local tax policies according to local tax laws and new levies which gives breadth to the local taxation authority is done by expanding the tax base. Giving to the local taxation authority have been duly carried out to confirm the alignments to the process of democratization. The problem is "how is the legal implications of the Land and Building Tax management of rural and urban sector after the enactment of Law no. 28 of 2009 on regional taxes and Retribution" To know the legal implications, the study begins first by performing comparative Land and Building Tax arrangement according to the Law. 12 of 1985 by Act no. 28 of 2009 on regional taxes and Retribution. The results of the study concluded that the policy of the Land and Building Tax management of rural and urban sectors is authorized for the district/city, which has implications on the necessity for coordination, transfer of assets, preparation of executive human resources, technology, device setup, institutional arrangements, legal instruments (regulations and declaring) as well as other supporting facilities and infrastructure.
\end{abstract}

Key words: Legal Implication, Policy, Land and Building Tax Management

\begin{abstract}
Abstrak
Kebijakan pajak daerah menurut UU Pajak daerah dan retribusi Daerah yang baru memberikan keluasan kewenangan perpajakan kepada daerah yang dilakukan dengan memperluas basis pajak. Memberikan kewenangan perpajakan kepada daerah sudah sewajarnya dilakukan untuk mempertegas keberpihakan kepada proses demokratisasi. Permasalahannya adalah " Bagaimanakah Implikasi Hukum "Pendaerahan" Pengelolaan PBB Sektor Perdesaan dan Perkotaan setelah berlakunya UU No. 28 Tahun 2009 tentang Pajak Daerah dan Retribusi Daerah " Untuk mengetahui implikasi hukum tersebut, maka kajian diawali terlebih dengan melakukan komparasi pengaturan PBB menurut ketentuan UU No. 12 Tahun 1985 dengan UU No. 28 Tahun 2009 tentang Pajak Daerah dan Retribusi Daerah. Dari hasil kajian disimpulkan bahwa Kebijakan pengelolaan PBB sektor Perdesaan dan Perkotaan menjadi wewenang Kabupaten/Kota, yang berimplikasi pada adanya keharusan untuk melakukan koordinasi, penyerahan asset, penyiapan Sumber Daya Manusia pelaksana, penyiapan perangkat teknologi, penataan kelembagaan, Instrumen yuridis (Perda maupun Perbub) serta Sarana dan Prasarana pendukung lainnya.
\end{abstract}

Kata kunci: Implikasi Hukum, Kebijakan, Pengelolaan PBB

\section{Pendahuluan}

Reformasi perpajakan di Indonesia (Tax Reform ) dicetuskan oleh pemerintah Indonesia pada tahun 1983 atau setelah 38 tahun Indonesia merdeka. Tax Rerorm pada dasarnya merupakan kebijakan pemerintah terhadap ketentuan perpajakan yang bersifat sangat mendasar yaitu mengenai prinsip, sistimatika serta dasar falsafahnya. Beberapa pertimbangan pemerin- tah melakukan reformasi perpajakan adalah karena banyaknya perundang-undangan pajak yang membingungkan rakyat. Pada saat itu pemerintah sudah mulai memebuat ketentuan mengenai perpajakan sementara ketentuan produk Hindia Belanda masih efektif berlaku, sehingga hak itu dipandang sangat membebani rakyat karena banyaknya macam pemungutan pajak. 
Reformasi pajak diharapkan akan lebih menegakkan kemandirian Indonesia dalam membiayai pembangunan nasional dengan jalan lebih mengarahkan potensi dan kemampuan dari dalam negeri melalui pajak dan sumbersumber di luar migas. Selain itu dengan reformasi pajak akan tercipta aparatur perpajakan yang lebih baik, sehingga lebih meningkatkan intensifikasi dan ekstensifikasi pemungutan pajak.

Salah satu produk perundang-undangan yang dihasilkan dalam rangka Tax Reform adalah dikeluarkannya Undang0undang tentang $\mathrm{Pa}$ jak Bumi dan Bangunan (PBB) yang diatur di dalam Undang-Undang Nomor 12 Tahun 1985. Beberapa undang-undang yang diganti atau dinyatakan tidak berlaku lagi dengan diundangkannya UU PBB Nomor 12 Tahun 1985 adalah Ordonansi Pajak Rumah Tangga 1908 (Personeele Belasting Ordonantie 1908, Staatsblad Tahun 1908 Nomor 13); Ordonansi Verponding Indonesia (Inlandsche Verponding Ordonantie 1923, Staatsblad Tahun 1923 Nomor 425); Ordonansi Verponding 1928 (Verponding Ordonantie 1928, Stbl. Tahun 1928 Nomor 324); Ordonansi Pajak Kekayaan (Ordonantie Op de Vermogens Belasting 1932, Staatsblad Tahun 1932 Nomor 405); Ordonansi Pajak Jalan 1942 (Weggeld Ordonantie 1942, Staatsblad Tahun 1941 Nomor 97); Pasal 14 huruf j, k dan I Undang-Undang Nomor 11 Drt Tahun 1957 tentang Peraturan Umum Pajak Daerah (Lembaran Negara Tahun 1957 Nomor 56, Tambahan Lembaran Negara Nomor 1287); Peraturan Pemerintah Pengganti Undang-Undang Nomor 11 Tahun 1959 tentang Pajak Hasil Bumi (Lembaran Negara Tahun 1959 Nomor 104, Tambahan Lembaran Negara Nomor 1860).

Setelah mendekati usia 25 tahun berlakunya UU PBB muncul wacana agar PBB dijadikan sebagai pajak daerah, ide ini kemudian lebih dikenal dengan upaya "Pendaerahan PBB". Penggagas pendaerah ketentuan tentang PBB beralasan bahwa obyek PBB bersifat tetap dan tidak berpindah, selain itu potensi dan perkembangannya lebih mudah dikelola oleh pemerintah daerah (kabupaten/kota). Pertimbangan lain dari pendaerahan PBB adalah da- lam rangka meningkatkan makna otonomi daerah. Otonomi daerah dapat membawa harapan yang menj aj ikan bagi keberhasilan mewujudkan pembangunan berkelanjutan. Dengan otonomi daerah, pemerintah daerah memiliki kewenangan untuk membuat sejumlah kebijakan yang sesuai dengan karakteristik wilayah dan aspirasi masyarakatnya. ${ }^{1}$ Sebagaimana dikemukakan oleh Muhammad Khusaini bahwa sebagai pajak yang berkaitan dengan properti, maka obyek PBB merupakan obyek yang immobile. Secara natural obyek yang bersifat immobile dimungkinkan dipungut secara lokal. ${ }^{2}$

Gagasan pendaerah PBB ini mendapat reaksi keras dari jajaran Direktorat J enderal Pajak. Suharno, salah seorang dari staf Direktorat J enderal Pajak mengatakan bahwa dalam kerangka negara kesatuan maka pengelolaan administrasi perpajakan secara sentralistik adalah paling tepat. ${ }^{3}$ Lebih Ianjut dalam tulisannya, Suharno menyimpulkan bahwa pengelolaan PBB oleh pusat mempunyai banyak keuntungan. Pertama, sistem administrasi PB yang sudah dikembangkan dengan teknologi informasi dan basis PBB yang sangat besar memiliki banyak manfaat (multipurposes) terutama dalam menggali sumber penerimaan PBB; kedua, NJ OP dapat dikembangkan sebagai nilai tunggal untuk berbagai keperluan (single value for multipurposes); ketiga, sistem informasi geografi PBB dapat dikembangkan sebagai embrio sistem informasi pertanahan multi guna (multipurpose land information system); dan keempat, dalam jangka panjang NJOP dapat dijadikan sebagai cadaster single information number

Dari sisi kerugian, tercatat banyak sekali kerugian jika PBB dijadikan sebagai pajak daerah yaitu pengelolaan PBB menjadi tidak efisien dan tidak memenuhi asas economic of scale,

Slamet Rosyadi dan Anwaruddin, "Otonomi Daerah Dan Upaya Mewujudkan Paradigma Pembangunan Berkelanjutan", Jurnal Sosial Ekonomi Humaniora, Vol. 2 No. 1, Mei-Oktober 2008, Purwokerto: LP Unsoed.

Muhammad Khusaini, 2006, Ekonomi Publik, Desentralisasi Fiskal dan pembangunan Daerah, Malang: Badan Penerbit FE Unibraw, hlm. 257.

3 Suharno, 2003, Pengelolaan Pajak Bumi dan Bangunan Dalam Era otonomi Daerah, J akarta: Direktorat PBB dan BPHTB, hlm. vii. 
terjadi kesenjangan penerimaan PBB antar daerah karena disparitas potensi PBB, munculnya perbedaan kebijakan pengelolaan PBB antar daerah, rawan dari pengaruh kepentingan politisi lokal dan pendataan dan penilaian obyek PBB menjadi uncontrollable. ${ }^{4}$ Lebih lanjut Suharno menyimpulkan bahwa pengelolaan administrasi PBB secara sentralistik bukanlah suatu penyimpangan atau kekeliruan, karena telah terbukti efisien dan telah memenuhi asas economic of scale. ${ }^{5}$

Terkait dengan wacana pendaerahan PBB, Muhammad Khusaini juga memberikan beberapa catatan tentang faktor-faktor yang harus diperhatiakan, yaitu biaya koleksi pajak, akan menjadi tanggungan daerah; masalah kepegawaian yang tentunya akan membengkan dan menjadi beban daerah; basis data PBB yang sudah tersusun rapi secara nasional akan menjadi rusak; dan potensi meningkatnya kesenjangan pendapatan antar daerah. ${ }^{6}$

Pemikiran "Pendaerahan" PBB direspon secara normatif oleh Pemerintah yaitu dengan digantikannya undang-undang No.34 Tahun 2000 menjadi Undang-Undang No.28 Tahun 2009. Dalam Ps 2 (2) UU PDRD yang baru di sebutkan bahwa Pajak Kabupaten/Kota meliputi Pajak Hotel; Pajak Restoran; Pajak Hiburan; Pajak Reklame; Pajak Penerangan Jalan; Pajak Mineral Bukan Logam dan Batuan; Pajak Parkir; Pajak Air Tanah; Pajak Sarang Burung Walet; Pajak Bumi dan Bangunan Perdesaan dan Perkotaan; dan Bea Perolehan Hak atas Tanah dan Bangunan.

Dibandingkan dengan UU PDRD lama, maka terdapat penambahan 3 (tiga) jenis pajak Kabupaten/Kota yang baru, yaitu PBB Pedesaan dan Perkotaan, Bea Perolehan Hak atas Tanah dan Bangunan (BPHTB), dan Pajak Sarang Burung Walet. Jenis pajak yang selama ini di-

\footnotetext{
Ibid.

Dengan melihat dan mencermati materi dan topik penulisan maka sepertinya buku tersebut diterbitkan khusus oleh Direktorat J enderal Pajak untuk mengcounter ide pendaerahan PBB. Hal ini semakin terlihat dengan kesimpulan yang merekomendasikan bahwa format pengelolaan administrasi PBB yang ideal dalam kerangka negara kesatuan adalah tetap mempertahankan sistim pengelolaan administrasi PBB secara sentralistis.

6 Muhammad Khusaini, Ibid.
}

pungut oleh Pusat, yaitu PBB Perdesaan dan Perkotaan dan BPHTB. Pemberlakuan pemungutan PBB dan BPHTB akan dilakukan secara bertahap. BPHTB akan dilaksanakan sepenuhnya oleh daerah pada tanggal 1 J anuari 2011, sedangkan PBB Perdesaan dan Perkotaan akan dilaksanakan sepenuhnya oleh daerah pada tanggal 1 J anuari 2014, sedangkan Pajak Sarang Burung Walet dapat dipungut oleh beberapa daerah apabila memiliki potensi pajak yang memadai.

Kebijakan "pendaerahan" PBB tentunya tidak terlepas dari kebijakan penyelenggaraan pemerintahan di Indonesia. Dalam Perkembangannya, penyelenggaraan pemerintahan di Indonesia telah mengarah kepada pelaksanaan otonomi luas. Pasca reformasi pemerintahan tahun 1998, Pemerintah memberikan keleluasaan kepada daerah untuk menentukan arah kebijakan pembangunan bagi daerahnya, yang dituangkan dalam wujud otonomi daerah seluas-luasnya dalam mengatur dan mengurus kepentingan masyarakat setempat. Kebijakan desentralisasi tersebut akan berhasil jika aparat pemerintah daerah cukup terlembaga sehingga mampu menciptakan tata pemerintahan yang demokratis. ${ }^{7}$ Perjalanan menuju pelaksanaan desentralisasl tersebut merupakan perwujudan konkrit akan adanya tuntutan pemberian otonomi yang luas kepada daerah. ${ }^{8}$

Pemerintah daerah dengan adanya otonomi dituntut untuk mempunyai kemampuan mengurus rumah tangganya sendiri baik dalam membuat rencana pembangunan, pelaksanaan maupun anggaran biaya dan tenaga pelaksanaan. namun dalam kenyatannya pengaturan kewenangan perpajakan dan retribusi yang ada saat ini kurang mendukung pelaksanaan otonomi Daerah. Pemberian kewenangan yang semakin besar kepada Daerah dalam penyelenggaraan pemerintahan dan pelayanan kepada masyarakat seharusnya diikuti dengan pem-

\footnotetext{
Wahyu Kumorotomo, 2008, Desentralisasi Fiskal (politik dan Perubahan Kebijakan 1974-2004), Jakarta: Kencana, hlm. 3.

8 Mardiasmo, 2009, Kebijakan desentralisasi Fiskal era Reformasi: 2005-2008, Dalam, Era Baru Kebijakan Fiskal, Editor: Anggito Abimanyu dan Andie megantara, J akarta: Kompas Buku, hlm. 561.
} 
berian kewenangan yang besar pula dalam perpajakan dan retribusi. Basis pajak kabupaten dan kota yang sangat terbatas dan tidak adanya kewenangan provinsi dalam penetapan tarif pajaknya mengakibatkan Daerah selalu mengalami kesulitan untuk memenuhi kebutuhan pengeluarannya.

Ketergantungan Daerah yang sangat besar terhadap dana perimbangan dari pusat dalam banyak hal kurang mencerminkan akuntabilitas Daerah. Pemerintah Daerah tidak terdorong untuk mengalokasikan anggaran secara efisien dan masyarakat setempat tidak ingin mengontrol anggaran Daerah karena merasa tidak dibebani dengan Pajak dan Retribusi. Untuk meningkatkan akuntabilitas penyelenggaraan otonomi daerah, Pemerintah Daerah seharusnya diberi kewenangan yang lebih besar dalam perpajakan dan retribusi.

Menurut Edi Slamet Iriyanto bahwa pajak merupakan faktor krusial dalam proses pembangunan dan penguatan simpul-simpul demokrasi di bidang ekonomi. Memberikan kewenangan perpajakan kepada daerah sudah sewajarnya dilakukan untuk mempertegas keberpihakan kepada proses demokratisasi. Kewenangan daerah dalam menentukan obyek pajak, basis pajak, memungut dan memanfaatkan uang pajak merupakan proyek penguatan posisi dan peran pemerintah daerah dalam roses pembangunan secara mandiri. ${ }^{9}$

Secara umum upaya yang dapat dilakukan oleh pemerintah daerah dalam rangka meningkatkan pendapatan daerah melalui intensifikasi pemungutan pajak dapat dilakukan dengan :Memeperluas basis penerimaan, Memperkuat proses penerimaan, Meningkatkan pengawasan, Meningkatkan efisiensi, Meningkatkan efisiensi administrasi dan menekan biaya pemungutan dan Meningkaatkan kapasitas penerimaan. ${ }^{10}$

Dari uraian latar belakang pemikiran tersebut di atas maka permasalahan yang muncul adalah "Bagaimanakah Implikasi Hukum Pengelolaan PBB Sektor Perdesaan dan Perkotaan

9 Edi Slamet Irianto, 2009, Pajak Negara Demokrasi, Konsep dan Implementasinya di Indonesia, Yogyakarta: LaksBang Mediatama, hlm. 242.

10 Adrian Sutedi, 2008, Hukum Pajak dan Retribusi Daerah, Bogor: Ghalia indonesai, hlm. 100. setelah berlakunya UU No. 28 Tahun 2009 tentang Pajak Daerah dan Retribusi Daerah" Untuk mengetahui implikasi hukum tersebut, maka kajian akan diawali terlebih dahulu dengan melakukan komparasi pengaturan PBB menurut ketentuan Undang-undang No. 12 Tahun 1985 sebagaimana telah dirubah terakhir dengan Undang-undang No. 12 Tahun 1994 dan pengaturan PBB menurut ketentuan Undang-undang No. 28 Tahun 2009 tentang Pajak Daerah dan Retribusi Daerah( Lembaran Negara RI Tahun 2009 No. 130 dan Tambahan Lembaran Negara RI No. 5049).

\section{Perbandingan Pengaturan PBB Pengaturan PBB Menurut UU No. 12 Tahun 1985 \\ Obyek Pajak}

Obyek Pajak dalam UU PBB adalah bumi atau bangunan yang berada di seluruh wilayah Republik Indonesia. Didalam UU No. 12 Tahun 1985 disebutkan bahwa yang termasuk pengertian bumi meliputi: permukaan bumi, perairan, seperti rawa-rawa, tambak pengairan, lebaklebung, laut wilayah Republik Indonesia termasuk tambang-tambang lepas pantai. Sedangkan pengertian bangunan adalah konstruksi teknik yang ditanam atau yang diletakkan secara tetap pada tanah dan atau perairan untuk tempat tinggal; tempat usaha atau tempat yang diusahakan, termasuk dalam pengertian bangunan adalah jalan lingkungan dalam satu kesatuan kompleks; Kolam renang; Pagar mewah; Tempat olah raga dan sebagainya.

\section{Subyek Pajak}

Subyek Pajak PBB sebagaimana diatur dalam Pasal 4 ayat (1) UU No. 12 Tahun 1985 adalah "orang pribadi atau badan yang secara nyata mempunyai hak atas bumi, dan/atau memiliki, menguasai, dan/atau memperoleh manfaat atas bangunan". Dalam hal tertentu bila atas suatu obyek pajak belum jelas diketahui wajib pajaknya maka Direktur J enderal Pajak mempunyai wewenang untuk menetapkan subyek pajaknya sebagai dimaksud ayat (1) di atas. 


\section{NJ OP dan NJ OPTKP}

Nilai jual obyek pajak (NJOP) adalah dasar pengenaan pajak yaitu harga rata-rata yang diperoleh dari transaksi jual beli yang terjadi secara wajar, dan bilamana tidak terdapat transaksi jual beli NJOP ditentukan melalui perbandingan harga dengan obyek pajak lain yang sejenis, atau nilai perolehan baru, atau nilai jual obyek pajak pengganti.

Untuk memudahkan pengenaan Pajak Bumi dan Bangunan diperlukan klasifikasi bumi dan bangunan menurut nilai jualnya. Sejak tahun 1999 klasifikasi ini ditetapkan dengan Keputusan Menteri Keuangan No. 523/ KMK.04/ 1998 disebutkan bahwa dalam menentukan klasifikasi bumi/tanah diperhatikan faktor-faktor letak, peruntukan, pemanfaatan, kondisi Lingkungan dan lain-lain, sedang dalam menentukan klasifikasi bangunan diperhatikan hal-hal sebagai berikut bahan yang digunakan, rekayasa, letak, kondisi lingkungan dan lain-lain.

Nilai J ual Obyek Pajak Tidak Kena Pajak (NJ OPTKP) adalah bagian dari NJ OP yang tidak dikenakan pajak, sehingga jumlah ini harus dikurangkan dari NJ OP terlebih dahulu sebelum diterapkan tarip. Pasal 3 ayat (3) UU No. 12 Tahun 1994 yang mulai berlaku 1 J anuari 1995 menyatakan bahwa besarnya NJ OPTKP adalah Rp. 8.000.000,- untuk setiap wajib pajak. Apabila satu wajib pajak mempunyai lebih dari satu obyek pajak maka yang diberikan NJ OPTKP hanya salah satu obyek pajak yang nilainya terbesar pada satu lokasi, sedangkan obyek pajak lainnya tetap dikenakan secara penuh tanpa dikurangi NJ OPTKP.

\section{Cara Menghitung PBB}

Untuk menghitung jumlah PBB harus diketahui terlebih dahulu tarip pajak dasar pengenaan pajak dan dasar penghitungan pajak. Tarip PBB adalah $0,5 \%$ dasar pengenaan adalah Nilai Jual Obyek Pajak (NJOP); dan dasar penghitungan pajak adalah Nilai Jual Kena pajak (NJ KP) atau assessment value yang menurut Peraturan Pemerintah Nomor 74/ 1998 tertanggal 30 September 1998 ditetapkan serendah-rendahnya $20 \%$ dan setinggi-tingginya $100 \%$ dari NJ OP.

\section{Tahun Pajak, Pendaftaran dan Pendataan}

Tahun pajak dalam PBB adalah jangka waktu satu tahun takwim atau 12 bulan, yaitu masa dari tanggal $1 \mathrm{~J}$ anuari sampai dengan 31 Desember tahun yang bersangkutan. Sehubungan dengan itu maka saat menentukan pajak yang terutang atau yang harus dibayar adalah ditentukan berdasarkan kondisi obyek pajak pada awal tahun pajak atau tanggal $1 \mathrm{~J}$ anuari tahun pajak yang bersangkutan.

Subyek Pajak harus mendaftarkan diri sebagai subyek pajak/wajib pajak. Pandaftaran dilakukan di Kantor Pelayanan Pajak Bumi dan Bangunan (atau Kantor Pajak Pratama) yang wilayah kerjanya meliputi letak tanah dan atas bangunan yang dimiliki, dikuasai atau dimanfaatkan oleh orang atau badan tersebut dengan menggunakan suatu formulir yang telah ditentukan oleh Direktur J enderal Pajak. Obyek yang harus didaftarkan oleh subyek pajak meliputi : Seluruh bumi/tanah yang dimiliki dengan suatu hak atau dimanfaatkan, dan seluruh bangunan yang dimiliki dan atau dikuasai atau dimanfaatkan.

Sarana Pendaftaran obyek pajak berupa bumi/tanah dan atau bangunan adalah suatu formulir yang disebut Surat Pemberitahuan Obyek Pajak disingkat SPOP. Kegiatan pendataan obyek pajak PBB terdiri dari 2 macam kegiatan, yaitu penyusunan data awal dan pemutakhiran data. Penyusunan Data Awal meliputi kegiatan penyampaian dan Pengembalian data SPOP. Kegiatan ini dilaksanakan oleh petugas KP PBB bekerjasama dengan aparat Pemerintah Daerah dan atau instansi lainnya dengan cara menyampaikan SPOP serta memantau dan menerima kembali SPOP. Kegiatan berikutnya adalah Pemutakhiran Data yang dilaksanakan oleh Petugas Pemerintah Daerah berdasarkan pelimpahan tugas dari Menteri Keuangan dan dilaksanakan berdasarkan petunjuk teknis yang diberikan oleh Ditjen Pajak. .

\section{Penagihan dan Pembayaran}

Dasar penagihan dalam PBB adalah Surat Pemberitahuan Pajak Terhutang (SPPT), Surat Ketetapan Pajak (SKP) atau Surat Tagihan Pajak (STP). Ketiga dasar penagihan pajak tersebut 
diterbitkan oleh Direktorat J enderal Pajak c.q. Kantor Pelayanan Pajak Bumi dan Bangunan (KP PBB). Selanjutnya jumlah pajak terhutang berdasarkan Surat Tagihan Pajak yang tidak dibayar pada waktunya dapat ditagih dengan Surat Paksa.

Untuk memperjelas uraian yang berkaitan dengan SPOP, SPPT dan penerbitan SKP berikut ini dibuatkan skema sistem pengenaan PBB
Administrasi PBB harus dilaksanakan dengan dukungan komputer.

\section{Keberatan dan Banding}

Waj ib pajak dapat mengajukan keberatan pada Direktur Jenderal Pajak atas diterbitkannya SPPT maupun SKP. Keberatan diajukan secara tertulis dalam jangka waktu 3 bulan sejak tanggal diterimanya SPPT/ SKP oleh WP,

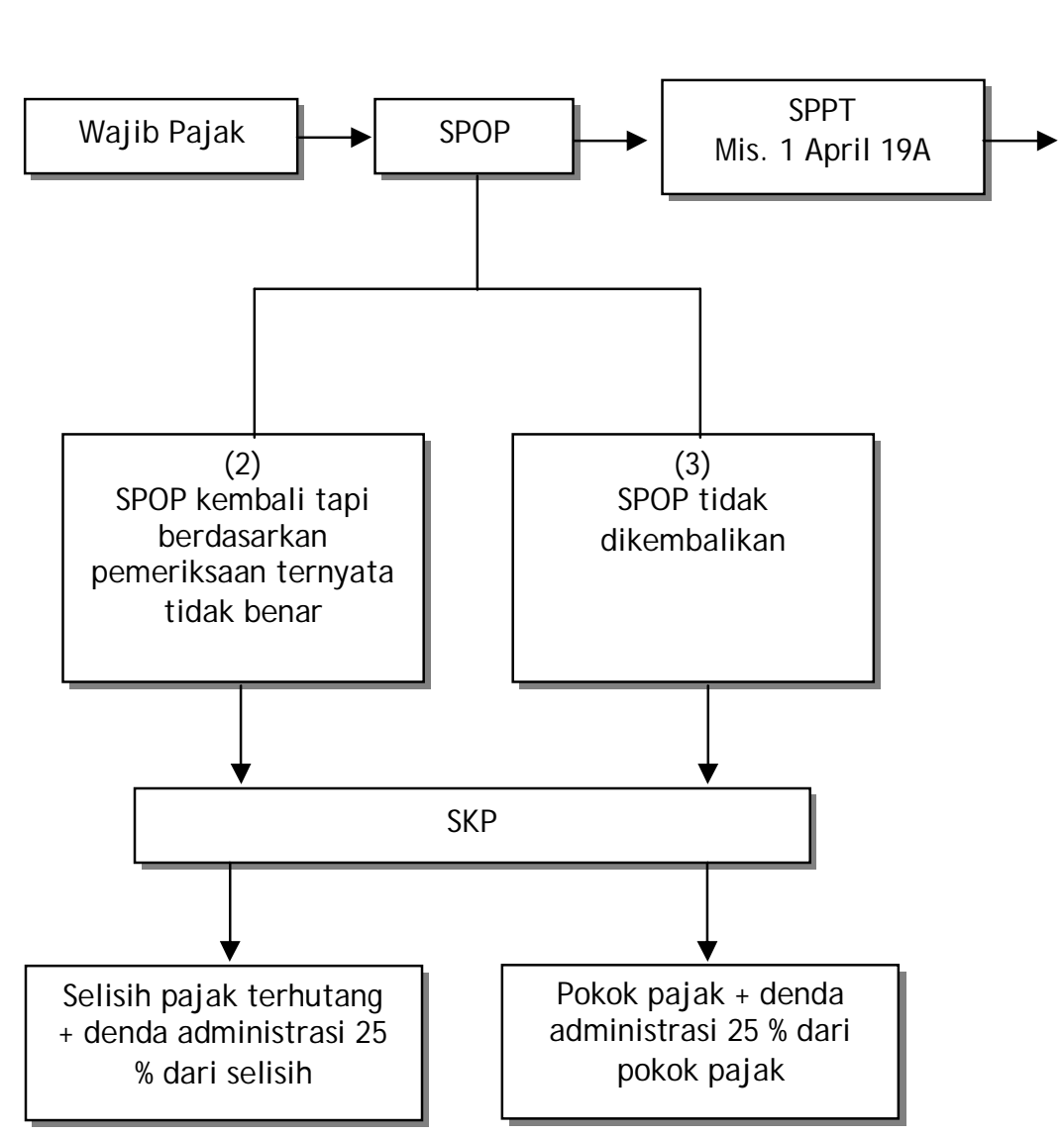

Pembayaran paling lambat tgl. 30 September 19A (1) Apabila terlambat : pajak yang terhutang + denda $2 \%$ bulan (maks $24 \mathrm{bln}$ ) Sarana menagih : STP

Sistem pemungutan dan pembayaran PBB semaksimal mungkin dilakukan dengan ketentuan sistematis, mudah dalam cara maupun administrasinya, Sederhana dalam cara maupun administrasinya dan dapat dilakukan monitoring dan pengawasan secara efektif dan efisien.

Sistem yang didambakan dapat memenuhi persyaratan tersebut kemudian dikenal dengan Sistem Tempat Pembayaran (SISTEP). Pokokpokok ketentuan Sistem Tempat Pembayaran adalah sebagai berikut : (1) Hanya ada satu tempat pembayaran untuk setiap wilayah pembayaran PBB tertentu, Penyampaian SPT kepada wajib pajak dilakukan secara serentak, kecuali apabila WP dapat menunjukkan bahwa jangka waktu itu tidak dapat dipenuhi karena keadaan diluar kekuasaannya dan pengajuan keberatan tidak menunda kewajiban membayar pajak. Terhadap hasil keputusan keberatan wajib pajak dapat mengajukan banding hanya kepada dana peradilan pajak. Permohonan banding diajukan dengan alasan yang jelas dan diajukan paling lama 3 bulan sejak surat keputusan keberatan diterima oleh wajib pajak.

\section{Pembagian Hasil Penerimaan Pajak}

Hasil penerimaan pajak merupakan penerimaan negara yang dibagi antara Pemerintah 
Pusat dan Daerah dengan imbangan pembagian sekurang-kurangnya 90\% untuk Pemerintah Daerah Kabupaten/Kota dan Pemerintah Propinsi sebagai pendapatan daerah yang bersangkutan. Imbangan pembagian hasil penerimaan pajak diatur dengan Peraturan Pemerintah No. 16 Tahun 2000 tanggal 10 Maret 2000, tentang Pembagian Hasil Penerimaan PBB Antara Pemerintah Pusat dan Daerah.

Peraturan tersebut mengatur tentang pembagian hasil penerimaan PBB, yaitu $10 \%$ untuk Pemerintah Pusat dan $90 \%$ untuk Daerah. Kemudian diatur pula jumlah $90 \%$ bagian Daerah, diperinci menjadi 16,2 \% untuk Daerah Propinsi yang bersangkutan; 64, 8 \% untuk Daerah Kabupaten/Kota yang bersangkutan; dan 9 $\%$ untuk biaya pemungutan. Bagian Pemerintah Pusat (10\%), dibagikan kepada seluruh Daerah Kabupaten/ Kota, yang didasarkan atas realisasi penerimaan PBB tahun anggaran berjalan dengan pembagian $65 \%$ dibagikan secara merata kepada seluruh Daerah Kabupaten/Kota; $35 \%$ dibagikan sebagai insentif kepada Daerah Kabupaten/Kota yang realisasi penerimaan PBB sektor pedesaan dan perkotaan pada Tahun Anggaran sebelumnya mencapai/melampui rencana penerimaan yang ditetapkan

\section{Penegakan Hukum}

Ketentuan tentang penegakan hukum diatur di dalam pasal yang mengatur tentang ketentuan Pidana. Ancaman pidana diterapkan kepada wajib pajak baik karena kesengajaan maupun kealpaannya tidak melakukan kewajiban perpajakan. Selain diatur di dalam UU Materiil, penegakan hukum juga diatur diatur di dalam UU Formil yaitu Undang-Undang Nomor 6 Tahun 1983 Tentang Ketentuan Umum Dan Tata Cara Perpajakan (KUP) yang telah mengalami beberapa kali perubahan.

\section{Pengaturan PBB di Dalam UU No. 28 Tahun 2009 Tentang PDRD}

Pajak daerah dan retribusi daerah merupakan salah satu sumber pendapatan daerah yang penting guna membiayai pelaksanaan pemerintahan daerah dan dalam rangka meningkatkan pelayanan kepada masyarakat dan kemandirian daerah, maka perlu dilakukan perluasan objek pajak daerah dan retribusi daerah dan pemberian diskresi dalam penetapan tarif. Atas dasar pertimbangan tersebut, maka Pemerintah mengeluarkan UU N0. 28 Tahun 2009 tentang Pajak Daerah dan Retribusi Daerah (UU PDRD) pada tanggal 15 September 2009 yang diundangkan dalam Lembaran Negara Republik Indonesia Tahun 2009 Nomor 130.

Secara yuridis formal PBB sudah berubah pengaturannya dari Pajak Pusat menjadi Pajak Daerah hanya memang di dalam UU tersebut ditegaskan bahwa yang menjadi Pajak Daerah hanya PBB sektor Perdesaan dan Perkotaan. Dan dari 185 Pasal yang ada di dalam UU PDRD ternyata ketentuan yang mengatur tentang PBB hanya ada di dalam Pasal 77 sampai dengan Pasal 84 ( 8 Pasal saja) ${ }^{11}$

\section{Obyek Pajak}

Objek Pajak Bumi dan Bangunan Perdesaan dan Perkotaan adalah Bumi dan/atau Bangunan yang dimiliki, dikuasai, dan/atau dimanfaatkan oleh orang pribadi atau Badan, kecuali kawasan yang digunakan untuk kegiatan usaha perkebunan, perhutanan, dan pertambangan. J enis obyek yang termasuk bangunan dan perkecualiannya sama dengan yang diatur din dalam UU no. 12 Tahun 1985.

\section{Subyek Pajak}

Subjek Pajak Bumi dan Bangunan Perdesaan dan Perkotaan adalah orang pribadi atau Badan yang secara nyata mempunyai suatu hak atas Bumi dan/atau memperoleh manfaat atas Bumi, dan/ atau memiliki, menguasai, dan/ atau memperoleh manfaat atas bangunan.

\section{NJ OP dan NJ OPTKP}

Nilai jual obyek pajak (NJOP) diatur di dalam Pasal 79. Di dalam pasal tersebut disebutkan bahwa Dasar pengenaan Pajak Bumi dan Bangunan Perdesaan dan Perkotaan adalah NJ OP. Besarnya NJ OP ditetapkan setiap 3 (tiga) tahun, kecuali untuk objek pajak tertentu dapat ditetapkan setiap tahun sesuai dengan

11 Bandingkan dengan PBB di dalam UU No. 12 Tahun 1994 yang terdiri dari XIV Bab dan 31 Pasal. 
perkembangan wilayahnya, penetapan besarnya NJ OP dilakukan oleh Kepala Daerah. Selanjutnya disebutkan bahwa besarnya Nilai Jual Objek Pajak Tidak Kena Pajak (NJ OPTKP) ditetapkan paling rendah sebesar Rp10.000.000,00 (sepuluh juta rupiah) untuk setiap Wajib Pajak. Penentuan Nilai Jual Objek Pajak Tidak Kena Pajak ditetapkan dengan Peraturan Daerah.

\section{Cara Menghitung PBB}

Untuk menghitung jumlah PBB harus diketahui terlebih dahulu tarif pajak dan dasar pengenaan pajak. Tarif PBB adalah 0,3\% tarif tersebut ditetapkan dengan Peraturan Daerah. Besaran pokok Pajak Bumi dan Bangunan Perdesaan dan Perkotaan yang terutang dihitung dengan cara mengalikan tarif dengan dasar pengenaan pajak (NJ OP) sebagaimana dimaksud dalam Pasal 79 ayat (3) setelah dikurangi Nilai J ual Objek Pajak Tidak Kena Pajak (NJ OPTKP) sebagaimana dimaksud dalam Pasal 77 ayat (5).

\section{Tahun Pajak, Pendaftaran dan Pendataan}

Tahun Pajak adalah jangka waktu 1 (satu) tahun kalender. Saat yang menentukan pajak yang terutang adalah menurut keadaan objek pajak pada tanggal $1 \mathrm{~J}$ anuari. Tempat pajak yang terutang adalah di wilayah daerah yang meliputi letak objek pajak. Pendataan dilakukan dengan menggunakan SPOP. SPOP sebagaimana dimaksud pada ayat (1) harus diisi dengan jelas, benar, dan lengkap serta ditandatangani dan disampaikan kepada Kepala Daerah yang wilayah kerjanya meliputi letak objek pajak, selambat-lambatnya 30 (tiga puluh) hari kerja setelah tanggal diterimanya SPOP oleh Subjek Pajak. Berdasarkan SPOP, Kepala Daerah menerbitkan SPPT.

\section{J atuh Tempo dan Tata Cara Pembayaran}

Kepala Daerah menentukan tanggal jatuh tempo pembayaran dan penyetoran pajak yang terutang paling lama 30 (tiga puluh) hari kerja setelah saat terutangnya pajak dan paling lama 6 (enam) bulan sejak tanggal diterimanya SPPT oleh Wajib Pajak. Ketentuan lebih lanjut mengenai tata cara pembayaran, penyetoran, tempat pembayaran, angsuran, dan penundaan pembayaran pajak diatur dengan Peraturan Kepala Daerah. Atas Permohonan Wajib Pajak, Kepala Daerah dapat mengeluarkan Keputusan Pembetulan, Pembatalan, Pengurangan Ketetapan, dan Penghapusan atau Pengurangan Sanksi administratif. Ketentuan mengenai tata cara pengurangan atau penghapusan sanksi administratif dan pengurangan atau pembatalan ketetapan pajak sebagaimana dimaksud diatur dengan Peraturan Kepala Daerah.

\section{Penegakan Hukum Keberatan dan Banding}

Waj ib Pajak dapat mengajukan keberatan hanya kepada Kepala Daerah atau pejabat yang ditunjuk. Keberatan diajukan secara tertulis dalam bahasa Indonesia dengan disertai alasanalasan yang jelas. Keberatan harus diajukan dalam jangka waktu paling lama 3 (tiga) bulan sejak tanggal surat, tanggal pemotongan atau pemungutan Keberatan dapat diajukan apabila Wajib Pajak telah membayar paling sedikit sejumlah yang telah disetujui Wajib Pajak. Untuk Banding, maka Wajib Pajak dapat mengajukan permohonan banding hanya kepada Pengadilan Pajak terhadap keputusan mengenai keberatannya yang ditetapkan oleh Kepala Daerah. Pengajuan permohonan banding menangguhkan kewajiban membayar pajak sampai dengan 1 (satu) bulan sejak tanggal penerbitan Putusan Banding. Ketentuan tentang pidana memuat ancaman bagi wajib pajak pajak yang baik karena kelalaiannya maupun karena kesengajaannya tidak melalukan kewajiban perpajakan.

\section{Pengawasan dan Pembatalan Perda Tentang Pajak}

Rancangan Peraturan Daerah kabupaten/ kota tentang Pajak dan Retribusi yang telah disetujui bersama oleh bupati/walikota dan DPRD kabupaten/ kota sebelum ditetapkan disampaikan kepada gubernur dan Menteri Keuangan paling lambat 3 (tiga) hari kerja terhitung sejak tanggal persetujuan dimaksud. Gubernur melakukan evaluasi terhadap Rancangan Peraturan Daerah yang diajukan oleh Kabupaten/ Kota untuk menguji kesesuaian Rancangan Peraturan Daerah dengan ketentuan Un- 
dang-Undang PDRD, kepentingan umum dan/ atau peraturan perundang-undangan lain yang lebih tinggi. Gubernur dalam melakukan evaluasi berkoordinasi dengan Menteri Keuangan. Hasil evaluasi yang telah dikoordinasikan dengan Menteri Keuangan tersebut dapat berupa persetujuan atau penolakan.

\section{Kebijakan Peralihan}

Kebijakan dalam masa peralihan tercantum di dalam ketenutan penutup yang menyebutkan bahwa Undang-Undang Nomor 12 Tahun 1985 tentang Pajak Bumi dan Bangunan (Lembaran Negara Republik Indonesia Nomor 68, Tambahan Lembaran Negara Republik Indonesia Nomor 3312) sebagaimana telah diubah dengan Undang-Undang Nomor 12 Tahun 1994 tentang Perubahan atas Undang-Undang Nomor 12 Tahun 1985 tentang Pajak Bumi dan Bangunan (Lembaran Negara Republik Indonesia Nomor 62, Tambahan Lembaran Negara Republik Indonesia Nomor 3569) yang terkait dengan peraturan pelaksanaan mengenai Perdesaan dan Perkotaan masih tetap berlaku sampai dengan tanggal 31 Desember 2013, sepanjang belum ada Peraturan Daerah tentang Pajak Bumi dan Bangunan yang terkait dengan Perdesaan dan Perkotaan.

\section{Pembahasan}

Tuntutan akan adanya pajak sebagai sumber pemasukan bagi kas negara mendorong adanya upaya pembaharuan pajak nasional. Hal tersebut tidak terkecuali pada Pajak Bumi dan Bangunan yang kelahirannya merupakan salah satu dari hasil reformasi pajak (tax reform), oleh karena itu strategi yang diambil pada pembaharuan pajak yaitu adanya kecenderungan mengutamakan pada penerimaan (revenue oriented $)^{12}$.

Sebagaimana dikatakan oleh Miyasto bahwa pada pembaharuan pajak I strategi perpajakan masih diarahkan pada bagaimana meningkatkan penerimaan pemerintah yang dapat digunakan untuk mebiayai kegiatan-kegiatan pembangunan, fungsi regulasi pajak yang ber-

12 Y. Sri Pudyatmoko, 2002, Pajak Bumi dan Bangunan, Yogyakarta: Andi Offset, hlm. 35. kaitan dengan peranan pajak dalam mengatur irama kegiatan ekonomi, alokasi sumber, konsumsi dan redistribusi pendapat, belum mendapatkan perhatian yang signifikan. ${ }^{13}$

Terlepas dari seberapa banyak peraturan perundangan itu dilakukan pembaharuan, namun yang perlu diperhatikan adalah bahwa di dalam pembuatan peraturan perundangan di bidang pajak harus selalu memperhatikan asas hukum pajak sebagai pikiran dasar yang umum sifatnya yang menjadi latar belakang dari suatu ketentuan konkrit ${ }^{14}$.

Adam Smith dalam buku yang berjudul The Wealth of Nation memberikan pedoman bahwa agar peraturan pajak memberikan rasa adil maka harus memenuhi 4 (empat) syarat yaitu adanya Equality and Equity, certainty, Convinience of Payment dan Economic of Collection. Keempat syart ini disebut "The Four Cannons of Adam Smith" atau sering disebut dengan "The Four Maxime" 15 .

Undang-undang tentang Pajak Daerah dan Retribusi Daerah diundangkan dengan pertimbangan bahwa pajak daerah dan retribusi daerah merupakan salah satu sumber pendapatan daerah yang penting guna membiayai pelaksanaan pemerintahan daerah, serta dalam rangka meningkatkan pelayanan kepada masyarakat dan kemandirian daerah, sehingga perlu dilakukan perluasan objek pajak daerah dan retribusi daerah dan pemberian diskresi dalam penetapan tarif; kebijakan pajak daerah dan retribusi daerah dilaksanakan berdasarkan prinsip demokrasi, pemerataan dan keadilan, peran serta masyarakat, dan akuntabilitas dengan memperhatikan potensi daerah. Atas dasar pertimbangan tersebut maka terdapat kebijakan baru di dalm UU PDRD, yaitu menetapkan beberapa jenis pajak menjadi Pajak derah Kabupaten/ Kota.

Terkait dengan kebijakan pendaerah PBB maka konsekwensi yuridis yang harus dilakukan oleh Pemerintah daerah (Pemda) adalah diharuskannya Pemda melakukan penyesuaian ke-

13 Miyasto, dalam Y. Sri Pudyatmoko, Ibid.

14 Sudikno Mertokusumo, 1991, Mengenal Hukum (Suatu Pengantar), Yogyakarta: Liberty, hlm. 33.

15 Adam Smith dalam Rochmat Soemitro, 1992, Asas dan Dasar Perpaj akan I, Bandung: PT. Eresco, hlm. 15. 
bijakan pengelolaan pajak daerah dan pembuatan instrumen yuridis dibidang perpajakan daerah. Beberapa kebijakan yang harus segera diambil atau paling tidak harus pikirkan menjelang diberlakukannya UU PDRD khususnya PBB.

\section{Penataan Kelembagaan}

Selama ini kelembagaan daerah yang menangani PBB berada dibawah koordinasi lembaga/dinas/instansi yang membidangi keuangan daerah. Dengan pendaerah PBB ini maka pemerintah daerah harus mempertimbangkan kemungkinan pembentukan lembaga baru yang khusus menangani Pajak daerah. Mengingat begitu luas dan kompleksnya permasalahan dibidang PBB maka akan sangat berat jika pengelolaan PBB disatukan menjadi urusan bidang atau seksi yang mengurusi masalah pajak daerah secara keseluruhan (Dinas Pendapatan Daerah atau yang sejenis). Pembentukan Dinas Pajak Daerah atau Kantor Pelayanan Pajak Daerah kiranya merupakan keniscayaan pembentukannya. Kiranya penataan kelembagaan ini menjadi sangat penting dalam rangka meningkatkan kepercayaan masyarakat, sebab salah satu masalah yang sedang dihadapi oleh bangsa Indonesia saat ini adalah menguatnya rasa ketidakpercayaan masyarakat terhadap pemerintah (public distrust), gejala yang paling menonjol dari adanya public distrust adalah adanya aksi menentang kebijakan pemerin$\operatorname{tah}^{16}$

\section{Penataan Sumber Daya Manusia}

Penataan sumber daya manusia sebagai pelaksana kebijakan dibidang PBB mutlak dilakukan mengingat beban kerja yang harus dipikul oleh aparat daerah adalah merupakan hal yang baru. Dikatakan baru, mengingat selama ini aparat daerah pelibatannya di dalam mekanisme pengelolaan PBB adalah bersifat pasif, segala sesuatunya sudah dipersiapkan oleh Pusat. Dengan pendaerahan PBB ini maka aparat

16 Kadar Pamuji, "Penguatan Lembaga Ombudsman Indonesia Dalam Rangka Mewujudkan Good Governance", J urnal Hukum, Vol 18 No. 1, Maret 2008, Semarang: Fak. Hukum Unisula daerah harus mampu secara mandiri melakukan operasionalisasi pemungutan PBB mempersiapkan segala sesuatu/sarana prasarana yang dibutuhkan untuk kegiatan mulai dari pendataan, pendaftaran sampai dengan mekanisme pembayaran. Bahwa faktor sumber daya manusia merupakankunci keberhasilan manajemen atau pengelolaan. Menguntip penjelasan Lembaga Administrasi Negara RI dikemukakan antara lain sebagai berikut: "jadi pada akhirnya faktor manusia itulah yang paling menentukan dan faktor yang mutlak mesti harus ada. Berhubung dengan itu, sebagian tersebar aktivitas manajemen benar-benar harus ditujukan kepada masalah-masalah manusianya,agar mereka memiliki sikap yang tepat, semangat yang baik, mampu menggunakan cara-cara kerja dan sarana-sarana lainnya dengan baik pula". ${ }^{17}$

Peningkatan kualitas SDM menjadi penting, meningkatnya kualitas SDM akan berdampak pada kinerja dan sikap mental pemerintah (aparat pajak). Pada era reformasi, upaya untuk mewujudkan sistem yang demokratis, bersih dan berwibawa telah menjadi prioritas utama bagi rakyat dan pemerintah. Reformasi birokrasi sebagai salah satu tuntutan reformasi telah menjadikan awal timbulnya kesadaran akan mekanisme birokrasi dan menjadi tonggak untuk menata sistem pemerintahan yang baik. ${ }^{18}$

Menurut Wacipto Setiadi, peningkatan SDM juga harus dilakukan di jajaran legislatif daerah (DPRD) mengingat dengan amandemen undang-undang dasar 1945, telah terjadi pergeseran dalam kekuasaan pembentukan undang-undang, yang sebelum undang-undang dasar 1945 diamandemen, kekuasaan pembentukan undang-undang titik beratnya berada di tangan eksekutif, tetapi dengan amandemen undang-undang dasar 1945 kekuasaan pemben-

\footnotetext{
17 A. A.Oka Mahendra, "Mekanisme Penyusunan Dan Pengelolaan Program Legislasi Daerah", J urnal Legislasi Indonesia, Vol. 3 No. 1, Maret 2006, Jakarta: Ditjend Peraturan Perundang-undangan RI.

18 Tedi Sudrajat, "Problematika Penegakan Hukuman Disiplin Kepegawaian", J urnal Dinamika Hukum, Vol. 3 No. 1, Maret 2006, Purwokerto: Fak. Hukum Unsoed.
} 
tukan undang-undang bergeser ke legislatif. ${ }^{19}$ Senada dengan hal tersebut diatas Machmud Aziz mengatakan bahwa Dalam pembentukan hukum tertulis khususnya peraturan perundangundangan, peran perancang (eksekutif atau legislatif) sangat stategis. Perancang adalah penyusun rancangan peraturan perundang-undangan yang bersifat hukum publik yang merupakan bagian integral dari lembaga pembentuk peraturan perundang-undangan. ${ }^{20}$

\section{Perumusan Kebijakan Teknis}

Perumusan kebijakan teknis pemungutan merupakan suatu hal yang harus dilakukan oleh Pemerintah Daerah. Kebijakan teknis dilakukan baik untuk mengantisipasi permasalahan yang mungkin timbul maupun dalam rangka pelaksanaan amanat UU. Kebijakan yang baik akan berpengaruh pada tingkat kepatuhan wajib pajak. Dalam sistem yang menekankan keaktifan wajib pajak, memerlukan tax compliance (kepatuhan perpajakan). Tax compliance tersebut sangat dibutuhkan untuk mengoptimalkan penerimaan pajak di Indonesia. ${ }^{21}$ Beberapa kebijakan teknis dalam rangka langkah antisipasi dijelaskan di bawah ini.

Pertama, melakukan Pendataan dan Pendaftaran Wajib Pajak. Pendataan wajib pajak harus kembali dilakukan, koordinasi dengan Ditjend Pajak yang mengurusi PBB merupakan suatu hal yang dapat dilakukan untuk memperoleh data wajib pajak. Data yang diperoleh dapat digunakan untuk melakukan kebijakan di dalam pendaftaran waj ib pajak.

Kedua, Penetapan NJ KP, NJ OP dan NJ OPTKP. Selama ini penentuan Nilai Jual Kena Pajak (NJ KP) atau biasa disebut dengan Assess-

19 Wicipto Setiadi, "Makna Persetujuan Bersama Dalam Pembentukan Undang-Undang Serta Penandatanganan Oleh Presiden Atas Rancangan Undang-Undang Yang Telah Mendapat Persetujuan Bersama", Jurnal Legislasi Indonesia, Vol. 1 No. 2, September 2004, Jakarta: Ditjend Peraturan Perundang-undangan RI

20 Machmud Aziz, "Problematika Jabatan Fungsional Perancang Peraturan Perundang-undangan (Legislative Drafter) dan Solusinya", J urnal Legislasi Indonesia, Vol. I No. 1 Juli 2004, Jakarta: Ditjend Peraturan Perundang-undangan RI.

21 Dahliana Hasan, "Pelaksanaan Tax Compliance Dalam Upaya Optimalisasi Penerimaan Pajak Di Kota Yogyakarta", J urnal Mimbar Hukum, Vol. 12 No. 2 J uni 2008, Yogyakarta: Fak. Hukum UGM. ment Value ditetapkan di dalam Peraturan Pemerintah, seperti PP Nomor 74/ 1998 tertanggal 30 September 1998 yang menentukan NJ KP sebesar $40 \%$ dan $20 \%$ tergantung dari obyek pajaknya. Di dalam UU PDRD tidak disebutkan di dalam pasal-pasalnya mekanisme penentuan NJ KP, walaupun secara sederhana dapat dikatakan bahwa NJ OP-NJ OPTKP = NJ KP. Undangundang PDRD Hanya mengamanatkan penentuan NJ OP dan NJ OPTKP, itupun dengan bentuk hukum yang berbeda, yaitu NJ OP ditetapkan setiap 3 (tiga) tahun, kecuali untuk obj ek pajak tertentu dapat ditetapkan setiap tahun dan dilakukan oleh Kepala Daerah (bentuk hukum dapat berupa Keputusan Bupatai atau Peraturan Bupati). Selanjutnya Nilai Jual Objek Pajak Tidak Kena Pajak (NJ OPTKP) ditetapkan paling rendah sebesar Rp10.000.000,00 (sepuluh juta rupiah) untuk setiap Wajib Pajak dan ditetapkan dengan Peraturan Daerah.

Ketika UU hanya mengamanatkan bahwa NJ OP ditetapkan oleh Bupati, maka produk hukum bisa dalam bentuk keputusan (Beschiking) bisa dalam bantuk peraturan (regeling). Hal ini tentu membutuhkan pemikiran dan pertimbangan yang matang, mengingat apabila produk hukum dalam bentuk keputusan, maka konsekwensinya adalah didalam penegakan hukum tentunya tunduk pada ketentuan yang mengatur tentang keputusan. Selain itu dengan dituangkannya dalam bentuk keputusan, maka tentunya ruang diskresi dari kepala daerah menjadi sangat dominan. Namun sebaliknya apabila NJOP dituangkan dalam bentuk Peraturan, maka ketentuan tersebut mengikat umum. Bupati mempunyai kewajiban untuk mendengarkan pertimbangan dari dewan (DPRD) sebelum mengeluarkan peraturan.

Terlepas apakah akan dituangkan dalam bentuk Keputusan maupun peraturan, yang jelas bahwa penentuan NJ OP mepunyai pengaruh terhadap penentuan jenis pajak yang lain. Sebagaimana kita ketahui bahwa NJ OP menjadi dasar penentuan PPh Final atas penjualan properti, PPn atas properti yang telah diserahkan oleh developer kepada pembeli, serta penen- 
tuan atas BPHTB atas hak yang telah diterima oleh pembeli22.

Sejak Tahun 2001 NJ OPTKP ditetapkan dengan melibatkan Pemerintah Daerah. Pelibatan dilakukan mengingat penentuan NJOPTKP secara langsung bersinggungan dengan stategic Policy, dalam arti menaikan atau menurunkan NJ OPTKP akan sangat berpengaruh terhadap pendapatan daerah dan perlindungan terhadap rakyat miskin di suatu daerah dan juga berpengaruh terhadap kualitas layanan publik (public service).

Seperti umumnya sifat kebijakan publik, maka kebijakan pajak juga dapat bersifat encouragement atau disecouragement, dalam arti kebijakan pajak dapat digunakan untuk mendorong atau suatu ketika dapat bersifat menghambat untuk suatu kegiatan ekonomi. Walaupun secara normatif dan ekonomis diharapkan bahwa kebijakan pajak bersifat netral, kerana netralitas pajak ini diharapkan akan tercipta alocation of resources yang efisien dan optimal sesuai dengan mekanisme pasar. ${ }^{23}$

Pada penentuan NJ OPTKP, daerah diberi kesempatan untuk menyalurkan aspirasinya dalam menyesuaikan pengelolaan PBB sesuai dengan kondisi dan keinginan daerah, apakah berorientasi pada penerimaan atau berorientasi pada perlindungan masyarakat kecil ${ }^{24}$. Untuk itu adalah sangat tepat jika penentuan NJ OPTKP kemudian diamantkan dalam bentuk Perda. ${ }^{25}$

Dituangkannya kebijakan dalam bentuk perda, maka secara ideal sebuah kebijakan akan lebih bersifat demokratis, transparan dan akuntabel yang pada akhirnya akan lebih memenuhi rasa keadilan bagi masyarakat. Kebijakan pajak yang hanya berorientasi pada pemasukan (budgetary Minded) maka akan muncul kecenderungan untuk melakukan tindakan apapun demi pemasukan kas negara.

22 Suharno, op.cit, hlm. 33.

23 R. Mansury, 2000, Kebijakan Perpajakan, Jakarta: Yayasan Pengembangan dan penyebaran Pengetahuan (YP4), hlm. 7.

24 Ibid, hlml. 31.

25 Di dalam UU No. 10 Tahun 2004 tentang Penyusunan Produk hukum, Perda adalah merupakan salah satu dari produk hukum yang berada di dalam tata urutan peraturan perundangan di Indonesia, yang dibuat oleh Bupati atas persetujuan bersama dengan DPRD
Kebijakan seperti ini boleh jadi akan mudah dirancang dan dilaksanakan dalam jangka pendek, tetapi dalam jangka panjang akan mendapat perlawanan dari wajib pajak minimum secara pasif dan latent. ${ }^{26}$

Ketiga, mekanisme pemungutan/penagihan dan bagi hasil. Dasar penagihan PBB adalah SPPT, SPT dan SKP, ketiganya diterbitkan oleh Direktorat Jenderal Pajak, yang dalam teknis pelaksanaannya dengan melibatkan aparat daerah sampai ke tingkat desa. Setelah pelimpahan maka wewenang melakukan penerbitan instrumen penagihan tersebut menjadi wewenang Kepala Daerah (Bupati/Walikota). Secara tegas di dalam UU PDRD disebutkan bahwa tata cara pembayaran, penyetoran, tempat pembayaran, angsuran, dan penundaan pembayaran pajak diatur dengan Peraturan Kepala Daerah. Amanat UU ini tentunya akan membawa konsekwensi bagi kepala daerah untuk mengeluarkan kebijakan dalam bentuk Peraturan Bupati (Pasal 146 ayat (1) UU No. 32 Tahun 2004).

Selain Peraturan Bupati yang memuat ketentuan sebagaimana tersebut diatas, maka tentunya harus dibuat ketentuan tetang teknis pemungatan/penagihan. Selama ini aparat daerah hanya dilibatkan sehingga bisa dikatakan kewenangannya terbatas. Namun dengan pendaerahan PBB ini aparat daerah lebih mempunyai kewenangan di dalam mekanisme penagiha dan pemungutan. Dengan amanat UU PDRD maka secara atributif Kepala Daerah memiliki kekuasaan untuk melakukan tindakan hukum, yang sebelumnya hanya mempunyai wewenang yang sifatnya terbatas (mandat).

Untuk kebijakan bagi hasil pajak antara Pemda dengan Pemerintah tingkat bawahnya mulai dari kecamatan, kelurahan sampai dengan desa perlu dipikirkan secara cermat. Banyak faktor yang harus dipertimbangkan dalam rangka perumusan kebijakan bagi hasil pajak, mulai dari luas wilayah, klasifikasi tanah dan bangunan, jumkah wajib pajak, ketepatan waktu pembayaran (terkait dengan insentif/stimulus/ perangsang).

26 Suharno, 2003, Pajak Properti (Kajian Teoritis dan Epiris), J akarta: Direktorat PBB dan BPHTB, hlm. 10. 


\section{Penegakan Hukum}

Ketentuan sanksi ini, baik pidana, perdata, maupun administratif merupakan suatu pilihan,artinya tidak harus ketiga-tiganya diterapkan tetapi dapat dipilih mana yang paling efektif dan yang paling tepat dikaitkandengan lingkup substansi pengaturannya. Bahkan sangat mungkin penegakan hukum dari suatu perundang-undangan sama sekali tidak diperlukan adanya sanksi.sanksi dalam peraturan perundang-undangan merupakan suatu opsi,jika diperlukan,termasuk ketentuan pidana.Oleh karena itu,dalam Iampiran Undang-Undang Nomor 10 Tahun 2004 tentang Pembentukan peraturan perundang-undangan ditentukan bahwa pencantuman ketentuan pidana dalam peraturan perundang-undangan adalah jika diperlukan. ${ }^{27}$

Konsep hukum administrasi negara dalam, penegakan hukum ditempuh melalui pengawasan dan penerapan sanksi. Pengawasan adalah langkah preventif untuk memaksa kepatuhan dan sanksi adalah langkah represif untuk memaksa kepatuhan warga terhadap norma hukum yang telah dibuat, dengan demikian penegakan hukum tidak selalu identik dengan sanksi ${ }^{28}$

Materi muatan pasal UU PDRD telah memuat ketentuan tentang penegakan hukum, mekanisme penegakan hukum berserta sanksi baik sanksi administrasi maupun sanksi pidan termuat di dalam pasal-pasal tersebut, hanya saja untuk operasionalnya ketentuan norma tersebut masih diperlukan peraturan pelaksana. Terkait dengan teknis pemungutan PBB maka terdapat banyak pasal yang mengamanatkan untuk adanya pembentukan Peraturan Kepala Daerah (Peraturan Bupati) sebagai pelaksanaan lebih lanjut pasal-pasal didalam UU PDRD. Pasal-Pasal yang mengamanatkan pembentukan Peraturan Kepala Daerah (Peraturan Bupati) dapat diperinci sebagai berikut :

27 Wicipto Setiadi, "Sanksi Administratif Sebagai Salah Satu Instrumen Penegakan Hukum Dalam Peraturan Perundang-Undangan", J urnal Legislasi Indonesia, Vol. 6 No. 4, Desember 2009, Jakarta: Ditjend Peraturan Perundang-undangan $\mathrm{RI}$.

28 Ridwan, 2009, Hukum Administrasi di daerah, Yogyakarta: UII Press, hlm. 122.

\begin{tabular}{|c|c|c|}
\hline No. & Pasal & Materi Muatan \\
\hline 1. & 1.46 & $\begin{array}{l}\text { Masa Pajak adalah jangka waktu } 1 \\
\text { (satu) bulan kalender atau jangka } \\
\text { waktu Iain yang diatur dengan } \\
\text { Peraturan Kepala Daerah......... }\end{array}$ \\
\hline 2. & $79(3)$ & $\begin{array}{l}\text { Penetapan besarnya NJOP seba- } \\
\text { gaimana dimaksud pada ayat ( } 2 \text { ) } \\
\text { dilakukan oleh Kepala Daerah. }\end{array}$ \\
\hline 3. & 99 & $\begin{array}{l}\text { (1) Tata cara penerbitan SKPD } \\
\text { atau dokumen lain yang di- } \\
\text { persamakan, SPTPD, SKPD- } \\
\text { KB, dan SKPDKBT sebagai- } \\
\text { mana dimaksud dalam Pasal } \\
96 \text { ayat (3) dan ayat (5) di- } \\
\text { atur dengan Peraturan Kepa- } \\
\text { la Daerah. } \\
\text { (2) Ketentuan lebih lanjut me- } \\
\text { ngenai tata cara pengisian } \\
\text { dan penyampaian SKPD atau } \\
\text { dokumen lain yang diper- } \\
\text { samakan, SPTPD, SKPDKB, } \\
\text { dan SKPDKBT sebagaimana } \\
\text { dimaksud dalam Pasal 96 } \\
\text { ayat (3) dan ayat (5) diatur } \\
\text { dengan Peraturan Kepala } \\
\text { Daerah. }\end{array}$ \\
\hline 4. & $101(4)$ & $\begin{array}{l}\text { Ketentuan lebih lanjut mengenai } \\
\text { tata cara pembayaran, penyetor- } \\
\text { an, tempat pembayaran, angsur- } \\
\text { an, dan penundaan pembayaran } \\
\text { pajak diatur dengan Peraturan } \\
\text { Kepala Daerah. }\end{array}$ \\
\hline 5. & $107(3)$ & $\begin{array}{l}\text { (3) Ketentuan lebih lanjut me- } \\
\text { ngenai tata cara pengurang- } \\
\text { an atau penghapusan sanksi } \\
\text { administratif dan pengurang- } \\
\text { an atau pembatalan kete- } \\
\text { tapan pajak sebagaimana di- } \\
\text { maksud pada ayat (2) diatur } \\
\text { dengan Peraturan Kepala } \\
\text { Daerah. }\end{array}$ \\
\hline 6. & $165(8)$ & $\begin{array}{l}\text { Tata cara pengembalian kelebih- } \\
\text { an pembayaran Pajak atau Retri- } \\
\text { busi sebagaimana dimaksud pada } \\
\text { ayat (1) diatur dengan Peraturan } \\
\text { Kepala Daerah. }\end{array}$ \\
\hline
\end{tabular}

Selain wewenang bupati untuk menerbitkan Peraturan Kepala Daerah sebagaimana tersebut di atas, Bupati masih diberi kewenangan teknis seperti; menerbitkan SPPT, SPT, menunjuk bank persepsi, menerbitkan keputusan penundaan pembayaran pajak, pengurangan maupun penghapusan denda dan masih banyak lagi.

\section{Ketentuan Peralihan}

Pasal 180.1 UU PDRD menyebutkan bahwa Undang-Undang Nomor 12 Tahun 1985 tentang 
Pajak Bumi dan Bangunan (Lembaran Negara Republik Indonesia Nomor 68, Tambahan Lembaran Negara Republik Indonesia Nomor 3312) sebagaimana telah diubah dengan Undang-Undang Nomor 12 Tahun 1994 tentang Perubahan atas Undang-Undang Nomor 12 Tahun 1985 tentang Pajak Bumi dan Bangunan (Lembaran Negara Republik Indonesia Nomor 62, Tambahan Lembaran Negara Republik Indonesia Nomor 3569) yang terkait dengan peraturan pelaksanaan mengenai Perdesaan dan Perkotaan masih tetap berlaku sampai dengan tanggal 31 Desember 2013, sepanjang belum ada Peraturan Daerah tentang Pajak Bumi dan Bangunan yang terkait dengan Perdesaan dan Perkotaan.

Pasal 180 tersebut di atas jika dibaca secara sepintas sepertinya merupakan suatu langkah antisipatif dimasa peralihan menuju pendaerah PBB. Materi muatan pasal tersebut seolah merupakan langkah untuk mengisi kekosongan hukum sambil menunggu diterbitkannya Perda PBB Perdesaan dan Perkotaan, akan tetapi jika kalimat tersebut diurai lebih lanjut maka akan terlihat beberapa permasalahan yuridis yang mungkin akan timbul.

Kalimat “... sepanjang belum ada Peraturan Daerah tentang Pajak Bumi dan Bangunan yang terkait dengan Perdesaan dan Perkotaan" mengandung pengertian bahwa secara yuridis formal usia UU No. 12 Tahun 1985 telah berakhir, tetapi usia tersebut kemudian diperpanjang sampai adanya Perda tentang PBB Perdesaan dan Perkotaan.

Suatu daerah yang sudah siap dengan berbagai konsekuensi beralinnya PBB menjadi Pajak Daerah, maka hal itu tidak menjadi persoalan, yang menjadi persoalan adalah apabila daerah tersebut belum siap. Jika suatu daerah secara formal maupun faktual belum siap maka daerah tersebut masih menggunakan UU No. 12 Tahun 1985 khususnya yang mengatur PBB perdesaan dan perkotaan, sesuai dengan amanat Pasal 180.1. Pertanyaannya adalah, pertama, sampai kapan daerah diberi toleransi untuk tetap menggunakan UU No. 12 Tahun 1985?; kedua, apakah dilingkungan Direktorat J enderal Pajak masih ada KP PBB khususnya sektor Perdesaan dan Perkotaan mengingat secara nasio- nal PBB Perdesaan dan perkotaan sudah didaerahkan?; ketiga, kepada siapa daerah harus menyetor uang PBB?; dan keempat, apakah mekanisme bagi hasil sebagaimana tercantum di dalam UU PBB masih berlaku?

\section{Penutup \\ Simpulan}

Berdasarkan uraian tersebut di atas dapat disimpulkan beberapa hal. Pertama, kebijakan perdaerahan PBB sektor Perdesaan dan Perkotaan bukan lagi merupakan wacana melainkan sudah dituangkan dalam bentuk norma, hal itu membawa konsekwensi bagi Pemerintah Pusat maupun Pemerintah Daerah dimasa peralihan yaitu sampai dengan batas waktu penerapan di tahun 2013 harus sudah melakukan langkah persiapan dan koordinasi untuk melakukan peralihan.

Kedua, pemerintah Pusat dalam hal ini Direktorat Jenderal Pajak Harus melakukan pendataan untuk melihat kabupaten/kota di Indonesia yang menunjukan kesiapannya mengelolaan PBB sektor Perdesaan dan Perkotaan di Tahun 2013, untuk selanjutnya diadakan koordinasi mengenai penyerahan asset khususnya yang terkait dengan data, informasi dan teknologi yang selama ini digunakan.

Ketiga, daerah yang berpotensi untuk menerima pelimpahan di Tahun 2013 harus sudah mulai melakukan langkah penyiapan yang terkait dengan persiapan Sumber Daya Manusia pelaksana, Teknologi, Kelembagaan, Instrumen yuridis (Perda maupun Perbub) serta Sarana dan Prasarana pendukung lainnya.

\section{DAFTAR PUSTAKA}

Aziz, Machmud. "Problematika Jabatan Fungsional Perancang Peraturan Perundangundangan (Legislative Drafter) dan Solusinya". J urnal Legislasi Indonesia. Vol. 1 No. 1. Juli 2004. Jakarta: Ditjend Peraturan Perundang-undangan Rl;

Hasan, Dahliana. "Pelaksanaan Tax Compliance Dalam Upaya Optimalisasi Penerimaan Pajak Di Kota Yogyakarta". Jurnal Mimbar Hukum. Vol. 12 No. 2. J uni 2008. Yogyakarta: Fak. Hukum UGM; 
Irianto, Edi Slamet. 2009. Pajak Negara Demokrasi, Konsep dan Implementasinya di Indonesia. Yogyakarta: LaksBang Mediatama;

Khusaini, Muhammad. 2006. Ekonomi Publik, Desentralisasi Fiskal dan pembangunan Daerah. Malang: Badan Penerbit FE Unibraw

Kumorotomo, Wahyu. 2008. Desentralisasi Fiskal (politik dan Perubahan Kebijakan 1974-2004). J akarta: Kencana

Mahendra, AA Oka. "Mekanisme Penyusunan Dan Pengelolaan Program Legislasi Daerah". Jurnal Legislasi Indonesia. Vol. 3 No. 1. Maret 2006. J akarta: Ditj end Peraturan Perundang-undangan Rl;

Mansury, R. 2000. Kebijakan Perpaj akan. J akarta: Yayasan Pengembangan dan penyebaran Pengetahuan (YP4);

Mardiasmo. 2009. Kebijakan desentralisasi Fiskal era Reformasi : 2005-2008, Dalam, Era Baru Kebijakan Fiskal. Editor: Anggito Abimanyu dan Andie megantara. Jakarta: Kompas Buku;

Mertokusumo, Sudikno. 1991. Mengenal Hukum (Suatu Pengantar). Yogyakarta: Liberty

Pamuji, Kadar. "Penguatan Lembaga Ombudsman Indonesia Dalam Rangka Mewujudkan Good Governance". J urnal Hukum. Vol. 18 No. 1. Maret 2008. Semarang: Fakultas Hukum Unisula;

Pudyatmoko, Y Sri. 2002. Pajak Bumi dan Bangunan. Yogyakarta: Andi Offset;

Ridwan. 2009. Hukum Administrasi di Daerah. Yogyakarta: UII Press;
Rosyadi, Slamet dan Anwaruddin. "Otonomi Daerah Dan Upaya Mewujudkan Paradig-ma Pembangunan Berkelanjutan". J urnal Sosial Ekonomi Humaniora. Vol. 2 No. 1. Mei-Oktober 2008. Purwokerto: LP Unsoed;

Setiadi, Wicipto. "Makna Persetujuan Bersama Dalam Pembentukan Undang-Undang Serta Penandatanganan Oleh Presiden Atas Rancangan Undang-Undang Yang Telah Mendapat Persetujuan Bersama". J urnal Legislasi Indonesia. Vol. I No. 2. September 2004. Jakarta: Ditjend Peraturan Perundang-undangan Rl;

"Sanksi Administratif Sebagai Salah Satu Instrumen Penegakan Hukum Dalam Peraturan Perundang-Undangan", J urnal Legislasi Indonesia. Vol. 6 No. 4. Desember 2009. Jakarta: Ditjend Peraturan Perundang-undangan $\mathrm{Rl}$;

Suharno. 2003. Pengelolaan Pajak Bumi dan Bangunan Dalam Era otonomi Daerah. J akarta: Direktorat PBB dan BPHTB;

Soemitro, Rochmat. 1992. Asas dan Dasar Perpajakan I. Bandung: PT. Eresco;

Sudrajat, Tedi. "Problematika Penegakan Hukuman Disiplin Kepegawaian". Jurnal Dinamika Hukum Vol. 3 No. 1. Maret 2006. Purwokerto: Fakultas Hukum Unsoed;

Suharno. 2003. Pajak Properti (Kajian Teoritis dan Epiris). Jakarta: Direktorat PBB dan BPHTB;

Sutedi, Adrian. 2008. Hukum Pajak dan Retribusi Daerah. Bogor: Ghalia indonesia. 